\title{
EFL TEACHING AT GOOD SENIOR HIGH SCHOOLS
}

\author{
Yudhi Arifani dan Ali Saukah \\ University of Muhammadiyah Gresik and State University of Malang \\ email: yudhiarif_76@yahoo.co.id
}

\begin{abstract}
Abstrak: Penelitian ini berusaha untuk mengungkap bagaimana guru-guru yang baik melaksanakan kegiatan pembelajaran yang baik di SMA unggulan. Empat dari enam belas guru Bahasa Inggris dari dua SMA unggulan dipilih berdasarkan kriteria standar guru dan kriteria tambahan. Data dikumpulkan melalui dokumentasi, observasi, dan wawancara. Hasil penelitian menunjukkan bahwa subjek memiliki kesamaan berikut: mereka (1) membangun komunikasi yang baik dengan siswa melalui pemodelan bahasa yang baik; (2) menjelaskan materi dengan cara deduktif dan induktif; (3) memberikan bantuan secara tidak langung; (4) melakukan koreksi kesalahan siswa secara tidak langsung; (5) mengecek pemahaman siswa melalui pertanyaan;(6) memberikan kesempatan kepada siswa untuk selalu terlibat dan praktik menggunakan bahasa Inggris.
\end{abstract}

Kata Kunci : pengajaran bahasa Inggris, sekolah unggulan

\section{EFL TEACHING AT GOOD SENIOR HIGH SCHOOLS}

\begin{abstract}
This study investigated how good EFL teachers implemented good EFL teaching activities at exemplary senior high schools. Four out of sixteen EFL teachers from two selected exemplary schools were chosen based on the criteria of the professional teachers' standard and some additional criteria. The data were collected through documentation, observation, and interviews. The results showed that the subjects had the following in common: they (1) built good communication with their students as a good model of EFL speakers; (2) explained materials through inductive and deductive ways; (3) provided assistance indirectly; (4) corrected students' errors indirectly; (5) checked students' understanding through questions; (6) provided language practice and involved students in all classroom activities.
\end{abstract}

Keywords: EFL teaching, good senior high schools

\section{INTRODUCTION}

One of the government efforts to improve the quality of education in Indonesia is through teacher certification based on a national standard of teachers. Standardization for teachers is regarded as a very essential aspect in the effort to improve the quality of education. Teachers play a very vital role to assure quality of education. Without qualified and standardized teachers, the educational process and objectives would be far beyond reach. Drost (2002) notes that the teacher's competence is more essential than other aspects of education. Kaplan and Owings (2007) also believe that "better teaching is the key to higher student achievement". It is then natural to assume that good teachers will generate good learners, as Patten (2003) puts it "good teachers help students realize their strengths and weaknesses and challenges the students to learn through those strength". However, how is good EFL teaching actually executed by good teachers?

The above question cannot be answered in a simple way. A teacher's job is very demanding; it does not stop at transferring knowledge to students or giving a test at the end of a lesson unit. Teachers must have certain competencies to be awarded the label of professional (Education Bill of the Republic of Indonesia No 14/2005). Related to the above question, Hoopingarne (2009) states that an effective teaching involves careful planning and imple- 
mentation of structured, engaging lessons anchored in critical thinking skills and designed for various learning styles. Moreover, according to Cruickshank, Jenkins \& Metcalf (2004), there are aspects which are essential to student learning and achievement: employment of effective teaching skills, teacher behavior and personality traits, and good classroom management strategies. It seems that pedagogical skills (designing lesson plans, managing and organizing the classroom, implementing new material, assessing and evaluating students) and personal skills (how teacher builds good relationship with students) in EFL teaching hold a very essential role to determine good teaching in the classroom.

Based on some preliminary study in Pendidikan dan Pelatihan Profesi Guru (PLPG, which is Teachers' Professional Training and Education), it was found that various EFL teachers implement different teaching practices in their classroom. A question can be raised: what are considered to be good EFL teaching practices; in other words, how good EFL teaching is implemented? This study tries to investigate how good EFL teaching is implemented at senior high schools considered to be exemplary schools in Malang.

\section{METHOD}

As ethnography this study attempted to figure out how individual EFL teachers executed good EFL teaching in the classroom setting and how the exemplary schools hold up good EFL practices. In this study, the culture related to individual EFL teacher was also investigated. It referred to the ways EFL teachers implemented EFL teaching in the classroom at the exemplary schools in Malang.

The subjects were selected after the exemplary schools were determined. First, two schools were selected out of five RSBI and SBI schools based on English academic performances of the schools, the average English Score at National Exam, schools accreditation and support toward EFL activities at the schools. Four out of sixteen EFL teachers from the two selected schools were selected as sub- jects based on four criteria, namely (1) Strata-1 degree holder in English education; (2) possessing professional teacher's certificates; (3) having at least six years' teaching experience; and (4) actively involved in Teachers' Forum. Other additional criteria such as attending overseas teachers' exchange program and becoming presenter in teachers' forum activity were also included to nominate the EFL teachers from the two selected schools as subjects of this study.

The data collection was conducted for six months. Classroom observations on the four EFL teachers' activities in the two schools were done in their preparation, implementation, and evaluation stages of teaching, and then interviews with subjects were done after the observations. In addition, the four subjects' teaching documents (teaching plan and teachers' made test) were also examined. Classroom observations were done twice for each teacher; totally eight times for all four teachers from the two schools. Interviews related to the implementation of EFL teaching at the schools were also done with three other EFL teachers, two nonEnglish teachers, and the two school principals.

The data related to the implementation EFL teaching in designing lesson plans and the EFL teaching practices in the class were analyzed simultaneously while collecting the data. The data analysis was done by applying constant comparative method to compare the implementation of EFL teaching among the four subjects. The documents of teaching plans from the four teachers of the two selected schools were analyzed and compared to see the commonalities on designing the lesson plans. Then, the four teachers' teaching practices in their classes were compared to reveal the same practices shared. In addition, EFL activities of the two schools were compared to reveal the kinds of school supports provided.

\section{RESULTS AND DISCUSSION Result}

At pre-teaching activities, it was revealed that good EFL teachers created good preteaching activities. They built good personal relationship with the students by showing that 
they know their students by their individual names which made the students feel closer to the teachers. The teachers activated students' prior knowledge by giving some questions related to the topic previously discussed. It was also used as a check for the teachers to decide whether they could continue with the other topic or they should re-explain the previous topic.

At whilst teaching activities, it was revealed that the teachers explained the material through inductive and deductive techniques under different conditions. Inductive teaching technique worked best if the students had enough vocabulary to talk about the topic. The teachers implemented deductive technique of teaching if the students were not familiar with the topic being taught and if the students did not have enough vocabulary to talk about the topic. EFL teachers took their role as a model, and the students just followed based on the model. Deductive technique of teaching worked best if the teachers involved their students to have language practice in the classroom. By doing so, the teacher avoided dominating their roles to explain the material in the classroom.

At the whilst stage, the teachers also provided indirect assistance when the students could not answer the teachers' questions, corrected students' language errors indirectly by repeating their expressions using the correct versions, checked students' understanding with some clarification questions, assisted the students indirectly with examples, clues, and simplification when they could not answer teachers' questions, and gave positive responses to the students regardless of whether they could and could not answer the questions correctly.

At the post-teaching stage, two activities were implemented. First, the teachers checked the students' understanding of the material they taught by giving the students questions to get feedback. As a result, the teachers knew what to do in the next teaching activities. Second, the teachers asked their students to do some homework.

\section{Discussion}

While lesson plan format varies across institutions, there are essential elements of a lesson plan generic to EFL teachers. These elements include: goals, objective, materials and equipments, procedures, evaluation and assignment (Brown, 2007). The results of the study show that the good EFL teachers conform with Brown's (2007) elements of good lesson plans: goals, objective, materials, procedures, and evaluation. The study also reveals that good EFL teachers write down their teaching goals and objectives referring to the standard of competence and measurable indicators of competence that should be achieved by the students in each meeting. The study also revealed that good activities should not only vary but also involve students in the meaningful activities to demonstrate, present, role play, and perform something, which conforms with Brown's principle of meaningful activities for learners (2007).

In creating good classroom interaction, good EFL teachers have to establish personal relationship with the students by showing that they know the students' names and responding to the students who were sick, for example, in appropriate English expressions. This reflects the teachers' personal competency which is considered as most essential in encouraging the students to learn (Anugerahwati, 2009; Sadik, 2007).

It is generally accepted that classroom interaction can facilitate students' language development and communicative competence. The role of classroom interaction is its contribution to language development by providing target language practice opportunities. It is also revealed that the teachers provide good classroom interactions through involving students to practice their language such as, answering questions, generating definition of the topic, summarizing the subject or the topic, and giving chance for classroom practice to use their English in the real communication.

In the study of interaction in EFL classes, $\mathrm{Yu}$ (2008) describes that classroom interaction is considered a productive teaching technique. Interaction facilitates not only language deve- 
lopment but also learners' development. They acquire linguistic knowledge and ability through interaction. The present research is in line with the previous studies conducted by Tarmopolsky (2001) and Yu (2008).

The result of this study provides alternative techniques of inductive and deductive teaching. They are complementary; teachers can combine those two models in their teaching under different conditions. In the study of inductive and deductive lessons for Saudi EFL freshman, Al-Kharrat (2008) notes that an inductive method involves students more in an analytical study of the language than the deductive method does. $\mathrm{He}$ also asserts that this method seems to be highly motivating and extremely beneficial for the students' understanding of the materials presented to them. The thinking skills that students employed in the inductive model are far more demanding than those use with the deductive model. Further, he also brings with the issue of whether or not it requires more experienced and advanced students.

In association with the use of teacher talks, the finding of this study supports the conclusion made by Liu \& Zhu (2012) in terms of the use of the types of teacher' questioning. In their study on the types of questions utilized by good EFL teachers they found that the teachers frequently provide the students with referential questions than display questions. The quality of teacher talks will be achieved if it is implemented through the real communication in the classroom activities. So, meaning negotiation can successfully be achieved. The uses of more referential questions offer more opportunity for learners to practice the target language.

In a study undertaken by Brock (1986), it was found that "higher frequencies of referential questions asked by teachers would have some effects on classroom discourse: students' responses to display questions would be shorter and syntactically less complex than their responses to referential questions; confirmation checks and clarification requests by the teacher would occur more frequently following referential questions than following display questions, and this would lead to more negotiation of meaning which is crucial to the target language acquisition." The result of the present study also shows that the teachers' questions contribute to the students' language development in elaborating their ideas into the target language.

In a research of comparative study between direct and indirect error correction, Erel (2007) reveals that there is no significant differrence between indirect coded feedback and direct feedback. The result of this study seems to give different arguments. The students tend to be less confident to participate in speaking when their teachers correct their errors directly in the classroom. It happens because they have psychological barriers with their classmates and it is so natural when students' errors are corrected directly in front of their peers, their self-confidence decreases.

Xiao-yan (2006) in his study on corrective feedback found that teachers correct immediately once students' errors occur. The result of the present study suggests that implied error correction works best if the teacher provides good language model by restating the students' expressions containing language errors in the correct versions. The students feel discouraged if the teacher corrects their language errors explicitly.

\section{CONCLUSION}

Good EFL teachers have the following in common: they (1) build good communication with their students as a good model of EFL teachers; (2) explain materials through inductive and deductive ways under different conditions; (3) provide assistance indirectly with examples and simplification; (4) correct students' errors indirectly; (5) check students' understanding through questions; (6) provide language practice and involve students in all classroom activities.

The implementation of EFL teaching in good schools is established if the school community facilitates diverse activities for EFL practices in the schools. 


\section{ACKNOLEDGEMENT}

Finnally, I would like to appreciation to Cakrawala Pendidikan Redactor, who helps me to make the article more insightful in this journal.

\section{REFERENCE}

Al-Kharrat, M.Y. 2008. "Deductive and Inductive Lessons for Saudi Freshmen Students". The Internet TESL Journal, Vol. VI, No. 10, October 2000. http://iteslj.org/.

Anugerahwati, M. 2009. A Profile of Good EFL Teachers. Unpublished. Dissertation. Malang: Graduate Program at State University of Malang.

Brock, A. C. 1986. "The Effects of Referential Questions on ESL Classroom Discourse". TESOL Quarterly, Volume 2, Issue 1, Pages 47-59, March 1986.

Brown, H.D. 2007. Principles of Language Learning and Teaching. Fourth Edition. New York: Pearson Education, Inc.

Cruickshant, J., \& Metcalf, K.K. 2004. Effective Teaching Method (4 ${ }^{\text {th }}$ Edition). Upper Saddle River, NJ: Prentice Hall, inc.

Drost, J. 2002. Reformasi Pengajaran. Grasindo: Jakarta.

Erel, S. 2007. "Error Treatment in L2 Writing: A Comparative study of Direct and Indirect Coded Feedback in Turkish EFL Context". Sosyal Bilimler Enstitüsü Dergisi Sayl : 22 Yll : 2007/1 (397-415 s.). http://sbe.erciyes.edu.tr/dergi/sayi_22/24$\% 20 \% 28397-415 . \% 20$ syf.\%29.pdf.

Government of the Republic of Indonesia. 2005. The Teachers and Lecturers Act No 14, 2005. Jakarta: Government of the Republic of Indonesia.

Hoopingarne, D. 2009. "Best Practices in Technologies and Language Teaching". Journal of Language and Linguistics Compass, Volume 3, Issue 1 Pages 222 - 235, January 2009.
Kaplan, L.S. and Owings, W.A. 2007. How Principals can Help Teachers with High Stakes Testing: One Survey's Findings with National Implications. http://bul.sagepub.com/content/85/622/15.short. Accessed Feb.02, 2009.

Liu, Min \& Zhu Lei. 2012. "An Investigation and Analysis of Teacher Talk in College English". International Journal of English Linguistics; Vo.2 No.5; September 2012. ISSN 1923-869X E-ISSN 1923-8703 Published by CanadianCenter of Science and Education. http://www.ccsenet.org/ijel.

Patten, B.C. 2003. What Makes Good Teacher. www.Idonline.org/articles/5696.

Purjayanti, A. 2007. "Good Language Teacher? Whose Perceptions? "A Paper Presented at the TEFLIN 55 ${ }^{\text {th }}$ International Conference. Conference Proceeeding Human Resources and Development. Jakarta: Jurusan Pendidikan Bahasa Inggris UIN Syarif Hidayatullah.

Sadik, A. 2007. "The Good Language Teacher? Students' Perspectives?" A Paper Presented at the TEFLIN $55^{\text {th }}$ International Conference. Conference Proceeeding Human Resources and Development. Jakarta: Jurusan Pendidikan Bahasa Inggris UIN Syarif Hidayatullah.

Tarnopolsky, O. 2000. "Teachers and the Global of Expansion English". ERIC Journal. Working Paper in Educational Linguistic. Vol.16 No. 2 p25-42 Fall 2000. http://www.eric.ed.gov/PDFS/ED452702.pdf.

Xiao-yan. 2006. Teacher Talks and EFL Classrooms. Unpublished Thesis in School of Foreign Language and Literature. Chongqing Normal University \& Yangtze Normal University.

Yu, Runmei. 2008. “Interaction in EFL Classes". Asian Social Journal. Vol. 4, No. 4, p 4850. April 2008. http://www.ccsenet.org/jounal.html. 